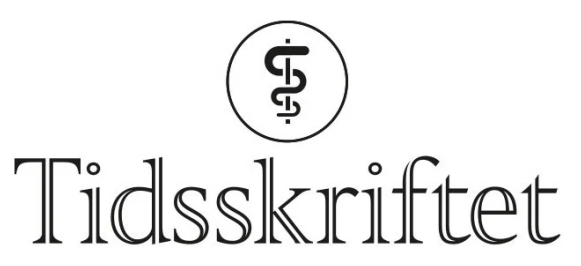

DEN NORSKE LEGEFORENING

\title{
Kommuneoverlegers opplevelse av egen rolle
}

\author{
ORIGINALARTIKKEL
}

\section{BETTINA C. FOSSBERG}

BettinaCaroline.Fossberg@lillestrom.kommune.no Tjenesteområde helse og mestring Lillestrøm kommune

Hun har bidratt med gjennomføring av studien, idé, innhenting av data, analyse og fortolkning samt utarbeiding av artikkelen.

Bettina C. Fossberg er spesialist i samfunnsmedisin med master i helseadministrasjon. Hun er leder av spesialitetskomiteen i samfunnsmedisin og kommuneoverlege i Lillestrøm kommune. Forfatteren har fylt ut ICMJE-skjemaet og oppgir ingen interessekonflikter.

\section{JAN C. FRICH}

Institutt for helse og samfunn

Universitetet i Oslo

Han har bidratt med veiledning og innspill gjennom hele prosessen samt revisjon av artikkelen.

Jan C. Frich er spesialist i nevrologi, professor ved Institutt for helse og samfunn, Universitetet i Oslo, og viseadministrerende direktør i Helse $S \emptyset r-\emptyset$ st.

Forfatteren har fylt ut ICMJE-skjemaet og oppgir ingen interessekonflikter.

\section{BAKGRUNN}

Alle kommuner er lovpålagt å ha en kommunelege som medisinskfaglig rådgiver, men bestemmer selv organiseringen av rollen. Stillingsstørrelse, plassering og innhold varierer mellom ulike kommuner. Vi gjorde en studie for å få økt kunnskap om hvordan kommuneoverleger opplever sin egen rolle.

\section{MATERIALE OG METODE}

Det ble samlet data fra fokusgruppeintervjuer med 15 kommuneoverleger fra ulike kommuner og fylker. Dataene ble gjenstand for tematisk kvalitativ analyse med bruk av systematisk tekstkondensering.

\section{RESULTATER}

Alle kommuneoverlegene var i rådgiverfunksjoner, og mange oppga liten tilgang på formelle beslutningsarenaer. Deres opplevelse var preget av rolleuklarhet og usynlighet, men også stor grad av autonomi. De fleste kommuneoverlegene ga uttrykk for å stå i skvis mellom behovene for rådgivning på to ulike nivåer: klinisk rådgivning i enkeltsaker og overordnet samfunnsmedisinsk rådgivning til ledelsen i kommunen. Opplevelsen var 
tydeligere hos kommuneoverleger i større kommuner enn i små. Organisatorisk ramme og forventninger fra ledelsen bidro til overvekt av etterspørsel etter klinisk rådgivning. Dette begrenset utviklingen av en samfunnsmedisinsk identitet og rolleutøvelse.

FORTOLKNING

Kommuneoverleger står i en hybridrolle som rådgivere på ulike nivåer som krever ulike identiteter. For å styrke den samfunnsmedisinske utøvelsen må rollen tydeliggjøres gjennom organisatoriske rammer og forventninger i kommunen.

\section{HOVEDFUNN}

Kommuneoverleger opplevde uklar rolleforståelse og usynlighet, men også stor grad av autonomi, og en dobbelthet i rollen mellom klinisk identitet og samfunnsmedisinsk identitet.

Organisatorisk ramme samt forventninger og oppfølging fra ledelsen påvirket kommuneoverlegens mulighet til å utvikle samfunnsmedisinsk identitet i store kommuner, mens stillingsstørrelse synes å være en viktig faktor i mindre kommuner.

Kommuneoverleger mente at opplevelsen av usynlighet og rolleuklarhet ville bli redusert hvis det ble lagt til rette for variert samfunnsmedisinsk arbeid.

Etter at samhandlingsreformen og folkehelseloven kom i 2012, er flere oppgaver overført fra spesialisthelsetjenesten til kommunene, og kommunene har fått mer ansvar for forebygging. Utviklingen har ført til et økende behov for medisinskfaglig rådgiving og ledelse (1-3) både i enkeltsaker i tjenesten og i kommuneledelsen. Kommunen er lovpålagt å ha en kommuneoverlege, som er den øverste medisinskfaglige rådgiveren (4.).

Kommunene står fritt til å bestemme egen administrasjonsordning og dermed også hvordan de organiserer kommuneoverlegerollen. Stillingsstørrelse og hvor stillingen er

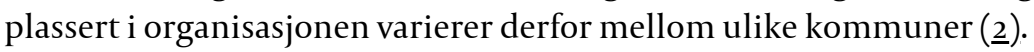

Det er flere ulike organisatoriske nivåer i en kommune. Øverste administrative leder er kommunedirektøren, som ofte har en stab med rådgivere. Under kommunedirektøren sitter kommunalsjefer. Disse har lederansvar for de ulike sektorene i kommunen og utgjør sammen med kommunedirektøren kommunens øverste administrative ledelse (nivå 1). På nivå 2 er rådgivere i kommunalsjefenes stab og ledere under kommunalsjefene. Nivå 3 er ledere under disse igjen. Store kommuner kan ha flere nivåer. De nederste nivåene er ofte de som gir tjenester direkte til befolkningen (tjenestenivå). Rollen som kommuneoverlege kan plasseres på ulike nivåer og i ulike sektorer i organisasjonen som rådgiver, leder eller ansatt.

Den fysiske plasseringen av stillingen kan være i nærheten av ledelsen på rådhuset eller på et kontor ute i tjenestene. Dette påvirker særlig den uformelle kontakten og synligheten i organisasjonen. Stillingsstørrelsen kan variere betydelig, og store kommuner kan ha flere kommuneoverleger. En rapport fra kommunesektorens organisasjon (KS) og Agenda Kaupang i 2016 viste at stillingsbrøken var underdimensjonert i mange kommuner (2 $)$ og at den kommunale ledelsens $\emptyset$ nske om medvirkning fra kommuneoverlegen varierte (1).

Kommuneoverlegen har sin faglige base i samfunnsmedisin. Samfunnsmedisin er befolkningsrettet (5), og viktige temaer i faget er smittevern, miljørettet helsevern, helsefremmende og forebyggende arbeid, kvalitetsarbeid og tilsyn, helseledelse og administrasjon, helseberedskap, helserett, kommunikasjon og rådgivning. Rollen kan deles inn i tre hoveddeler (므). Kommuneoverlegen er lokal helsemyndighet, hjemlet direkte i lovverk innenfor bl.a. smittevern, miljørettet helsevern og psykisk helsevern. Videre er kommuneoverlegen medisinskfaglig rådgiver, både eksternt til befolkningen og 
internt i kommunen - på individnivå, gruppenivå eller befolkningsnivå. Til slutt har rollen en administrativ del som ofte består av administrering av fastlegeordningen samt ansvar for LIS1-kandidater og spesialisering av leger.

Uavhengig av rollens plassering må kommuneoverlegen forholde seg til ulike organisatoriske kommunenivåer: både individsaker på tjenestenivå og systemsaker på ledelsesnivå. Individsaker kan kreve mer klinisk kompetanse, mens systemsaker krever samfunnsmedisinsk kompetanse. Skillet er ikke skarpt, men de to typene rådgivning trekker i ulik retning. Kommuneoverleger utøver derfor en form for «hybridledelse» (7-11), der man må forene to ulike identiteter og logikker som drar i ulike retninger. En vellykket hybridleder klarer å sjonglere og kombinere de to identitetene (7.), men en slik rolle kan gi identitets- og rollekonflikter $(\underline{10})$. Flere studier har vist at leger først og fremst identifiserer seg med behandlerne i helsevesenet, ikke med de administrative lederne $(7, \underline{12})$. Å utvikle en samfunnsmedisinsk identitet som kommuneoverlege kan derfor være utfordrende (7.).

I en tid med $\emptyset \mathrm{kt}$ behov for medisinskfaglig rådgivning på flere nivåer ønsket vi å unders $\emptyset \mathrm{ke}$ hvordan kommuneoverleger i ulike kommuner opplevde egen rolle og hva som påvirket deres opplevelse.

\section{Materiale og metode}

Bakgrunnen for studien var et ønske om mer systematisk kunnskap om opplevelsen av å være kommuneoverlege. Førsteforfatter har flere års erfaring som kommuneoverlege og spesialist i samfunnsmedisin og hadde kjennskap til at ulike kommuner har ulike rammer for rollen. Det ble valgt et kvalitativt design med fokusgruppeintervjuer av kommuneoverleger. Fokusgruppeintervjuer er en etablert metode for datainnsamling som egner seg godt til å utforske erfaringer hos helsepersonell (13). De gir data både direkte fra enkeltdeltakerne og fra diskusjoner og refleksjoner på tvers i gruppen (14).

UTVALG

Det ble sendt ut forespørsel om deltakelse i studien til tre ulike hovedgrupper med kommuneoverleger: to var etablerte interkommunale samfunnsmedisinske nettverk, én besto av en gruppe leger i spesialisering som deltok på et grunnkurs i samfunnsmedisin. Informasjon om studien og samtykkeskjema ble sendt på e-post til totalt 51 personer. Av disse takket henholdsvis seks og fem deltakere i etablerte samfunnsmedisinske nettverk og fire leger i spesialisering ja til å delta. De to etablerte nettverkene besto av kommuneoverleger fra kommuner i to ulike områder i Sør-Norge som møttes jevnlig for å dele erfaringer og diskutere faglige utfordringer og spørsmål. Gruppen med leger i spesialisering på kurs kom fra hele landet og kjente hverandre ikke godt fra tidligere.

De tre fokusgruppeintervjuene hadde til sammen 15 deltakere, 10 kvinner og 5 menn, og ble gjennomført i perioden desember 2018 til oktober 2019. Informantene representerte 13 ulike kommuner og fem ulike fylker i Sør-Norge. Gjennomsnittlig alder var 54,4 år. Erfaringen som kommuneoverlege varierte fra fire måneder til over zo år, med en median erfaring på åtte år. Syv av de femten var spesialister i samfunnsmedisin, syv var under spesialisering og én var ikke spesialist. Halvparten av utvalget jobbet i store kommuner, mens resten jobbet i små eller mellomstore kommuner. Stillingsstørrelsen varierte fra $20 \%$ til 100\%, med en median på $70 \%$ og et gjennomsnitt på $67 \%$. Ingen små eller mellomstore kommuner i utvalget hadde kommuneoverleger i $100 \%$ stilling. Gjennomsnittlig stillingsstørrelse i disse kommunene var $50 \%$ (tabell 1).

\section{Tabell 1}

Oversikt over utvalget av kommuneoverleger i studien. 


\begin{tabular}{|c|c|c|c|c|c|}
\hline & Kjønn & $\begin{array}{l}\text { År med } \\
\text { erfaring }\end{array}$ & $\begin{array}{l}\text { Spesialisering i } \\
\text { samfunnsmedisin }\end{array}$ & $\begin{array}{l}\text { Kommunestørrelse } \\
\text { (innbyggere) }\end{array}$ & $\begin{array}{l}\text { Stillingsstørrelse } \\
(\%)\end{array}$ \\
\hline 1 & Mann & $5-10$ & Under spesialisering & 10 000-19999 & 80 \\
\hline 2 & Kvinne & $5-10$ & Spesialist & $>20000$ & 100 \\
\hline 3 & Kvinne & $>10$ & Under spesialisering & $>20000$ & 100 \\
\hline 4 & Mann & $>10$ & Spesialist & $>20000$ & 80 \\
\hline 5 & Kvinne & $<5$ & Under spesialisering & $>20000$ & 50 \\
\hline 6 & Kvinne & $<5$ & Under spesialisering & $>20000$ & 40 \\
\hline 7 & Kvinne & $<5$ & Under spesialisering & $<4999$ & 40 \\
\hline 8 & Kvinne & $5-10$ & Under spesialisering & $5000-9999$ & 50 \\
\hline 9 & Mann & $<5$ & Under spesialisering & $10000-19999$ & 50 \\
\hline 10 & Kvinne & $>10$ & Spesialist & $>20000$ & 70 \\
\hline 11 & Kvinne & $5-10$ & Spesialist & $>20000$ & 100 \\
\hline 12 & Mann & $>10$ & Spesialist & $<4999$ & 50 \\
\hline 13 & Kvinne & $5-10$ & Spesialist & $>20000$ & 80 \\
\hline 14 & Mann & $>10$ & Ikke spesialist & $5000-9999$ & 20 \\
\hline 15 & Kvinne & $>10$ & Spesialist & $>20000$ & 100 \\
\hline
\end{tabular}

Fokusgruppeintervjuene varte i gjennomsnitt i 60 minutter. Det ble utarbeidet og benyttet en intervjuguide som inneholdt blant annet spørsmål rundt organisering, hvor godt kompetansen var kjent i kommunen, etterspørsel etter rådgivning, innflytelse samt fremmere og hemmere av god rolleutøvelse. Punktene i malen ble alltid tatt opp, samtidig som oppståtte refleksjoner underveis ble utforsket og fulgt opp med nye spørsmål. På den måten fikk deltakerne bidratt både med innspill til de fastsatte punktene og med nye refleksjoner. Førsteforfatter gjennomførte intervjuer og analyse med veiledning fra andreforfatter. Under intervjuene ble det gjort lydopptak. Disse ble transkribert manuelt av førsteforfatter og anonymisert med krypteringsnøkkel etter gjeldende personvernreglement. Lydopptakene ble deretter slettet.

\section{ANALYSE}

Organisasjons- og ledelsesteorier utgjorde en teoretisk referanseramme og inspirasjon for prosjektet, men det ble ikke laget noen forhåndsdefinerte kategorier for analysen. Dataene ble gjenstand for tematisk kvalitativ analyse med bruk av systematisk tekstkondensering (13). Analysemetoden har fire trinn. Både i forkant, underveis og i etterkant av de ulike trinnene i analysen ble det diskutert mellom forfatterne. Først ble det etablert en oversikt over teksten og en inndeling i foreløpige temaer som reflekterte forskningsspørsmålet. I neste trinn ble de foreløpige temaene utviklet videre til kodegrupper. Teksten ble da brutt ned til mange ulike meningsbærende enheter, som så ble sortert og systematisert i ulike kodegrupper.

Kodegruppene ble slått sammen, justert og revidert i flere runder, og for hver runde ble det laget et eget dokument som forfatterne diskuterte seg imellom. I tredje trinn av analysen ble det laget et sammendrag av innholdet i de ulike meningsbærende enhetene, og i siste 
trinn ble resultatet av analysen satt sammen til en tekst hvor enkelte sitater fra intervjuene ble tatt med. Teksten ble til slutt validert ved at de originale intervjuene ble lest på nytt for å sikre at det ferdige resultatet ga et riktig bilde av det opprinnelige materialet.

ETIKK

Før oppstart ble prosjektskisse med utarbeidede informasjonsskriv og samtykkeskjema sendt inn og godkjent av Norsk Senter for forskningsdata (NSD).

\section{Resultater}

I analysen ble det laget to oppsummerende begreper om kommuneoverlegenes opplevelse av egen rolle: usynlighet og rolleuklarhet. Disse opplevelsene var særlig preget av den organisatoriske rammen, oppfølging og forventninger fra ledelsen samt egen kompetanse og engasjement. De fleste fortalte at de ble dratt mellom behovene for rådgivning på ulike nivåer: i enkeltsaker på tjenestenivå og overfor ledelsen på overordnet nivå. Det var bred enighet om vanskeligheter med å definere rollen tydelig, og utøvelsen av denne ble preget av legens engasjement og interesse og varierte fra kommune til kommune.

USYNLIGHET

Ulike kommuneoverleger beskrev i studien en følelse av å være lite synlig for egen leder eller i organisasjonen som helhet, av å ha mindre påvirkningskraft fordi de var utenfor beslutningsarenaer og av å være utenfor faglige og sosiale fellesskap. Begrepet usynlighet er brukt for å oppsummere alle disse opplevelsene og rommer både synlighet, anerkjennelse og integrasjon. Opplevelsen av usynlighet var stort sett negativ, men ga også en positiv opplevelse av autonomi. Den var gjennomgående sterkere hos kommuneoverleger fra mellomstore eller store kommuner.

Usynlighet ble særlig påvirket av organisatorisk ramme. De fleste kommuneoverlegene var organisert som rådgivere på nivå 2 , men noen var plassert lenger ned i organisasjonen. De som var langt ned i organisasjonen i større kommuner, beskrev opplevelsen av å være lite synlig utenfor eget område. I mellomstore og store kommuner ble også fysisk plassering trukket frem som viktig. De som satt langt unna egen leder eller kommunens ledelse opplevde at det ga mindre involvering i overordnede saker. En kommuneoverlege beskrev følelsen av usynlighet slik: «Det er ingen som vet hva jeg gjør eller ikke gjør ... og ingen spør [oppgitt latter].» (kommuneoverlege, deltaker 4)

I mindre kommuner hadde organisatorisk og fysisk plassering mindre å si for kommuneoverlegenes opplevelse av synlighet. Kommuneoverlegene opplevde å ha mer kontakt på uformelt nivå på tvers av nivåer og sektorer. Stillingsstørrelse ble imidlertid beskrevet som avgjørende for hvor synlige de rakk å være.

Tverrsektorielt arbeid ble tatt opp som viktig for god rolleutøvelse i alle fokusgruppene. Det var bred enighet om at dette var krevende å gjennomføre i praksis. Flere kommuneoverleger deltok i ulike rådgivende team, men få satt i ledergrupper. Manglende tilgang på beslutningsarenaer ble sett på som en utfordring, særlig i mellomstore og store kommuner. De fleste opplevde å få god tilgang på beslutningsarenaer i kriser, men beskrev at de mistet denne tilgangen når krisen var over. Dette bidro til en følelse av usynlighet i hverdagen.

«Så jeg er en sånn typisk skapnisse. Altså, når det smeller skikkelig, så henter de meg ut. Og så, når man er ferdig med saken, så pakker de meg bort igjen.» (kommuneoverlege, deltaker 13)

Til slutt var det enkelte opplevelser som ble gjentatt av flere kommuneoverleger som bidragende til en følelse av usynlighet og ensomhet. Den ene var opplevelsen av å stå i konstant 24 timers beredskap. De færreste hadde beredskapsordninger, og flere opplevde manglende anerkjennelse av belastningen dette medførte. Dette $\emptyset$ kte følelsen av å ikke bli sett eller forstått. Mange beskrev også at leder kjente dårlig til deres kompetanse og at dette 
medførte redusert involvering i samfunnsmedisinske saker. Opplevelsen av å stå utenfor det faglige og sosiale fellesskapet i kommunen ble tatt opp av flere, særlig av kommuneoverleger i mellomstore og store kommuner. Å stå utenfor ga mye frihet, men også følelsen av usynlighet og ensomhet.

«Jeg synes fortsatt at jeg er litt eremitt på en måte. Sånn sosialt, da, i organisasjonen. Det tror jeg er betegnende for mange kommuneoverleger. At man jobber ganske alene. Man kan ha mange samarbeidsarenaer, men likevel ... så er du alene.» (kommuneoverlege, deltaker 1)

Viktigheten av kollegiale nettverk på tvers av kommunene ble derfor presisert i alle fokusgruppene.

\section{ROLLEUKLARHET}

De fleste kommuneoverlegene fortalte at de var vedvarende usikre på hvordan de skulle fylle rollen. Dette var sterkest hos dem med kortest erfaring og minst samfunnsmedisinsk kompetanse, men også de erfarne kommuneoverlegene kunne kjenne seg igjen i dette. Det var særlig to ting som bidro til den uklare rolleforståelsen: egen samfunnsmedisinsk kompetanse og ledelsens rammer og forventninger.

De fleste kommuneoverlegene kom fra kliniske stillinger før de startet i samfunnsmedisin. Flere beskrev rolleuklarheten i starten av karrieren som en konsekvens av liten erfaring og kompetanse samt få rammer fra ledelsen. En fersk kommuneoverlege beskrev det slik: «En del av de lovpålagte oppgavene mine er satt litt rundt til andre. Så da er spørsmålet, hva sitter jeg igjen med, liksom? Jeg føler at det er litt sånn ullent, disse arbeidsoppgavene.» (kommuneoverlege, deltaker 9)

Flere av kommuneoverlegene beskrev at de med økende samfunnsmedisinsk kompetanse $\emptyset$ nsket seg inn på ulike arenaer i kommunen for å bidra med rådgivning og myndighet. Dette ble opplevd som viktig for å utøve rollen godt. Ved manglende tilgang til slike arenaer og oppgaver, eller ved manglende forventninger fra ledelsen om slik rådgivning, beskrev flere en usikkerhet og uklarhet i egen rolleforståelse. Kommuneoverleger fra mindre kommuner opplevde å ha god tilgang på ulike arenaer og oppgaver i kommunen. De tok opp egen kompetanse og manglende forventninger fra ledelsen som viktigste årsak til eventuell uklar rolleforståelse. Kommuneoverleger fra større kommuner beskrev manglende tilgang på samfunnsmedisinske oppgaver utenfor helsetjenesten som den fremste kilden til uklar rolleforståelse.

«Det stedet hvor det er enklest å få oppdrag er i helsetjenesten. Jeg kan bare vise meg på gangen, så drukner jeg. Så det er ikke noe problem å få oppdrag i helsetjenesten, men det er kanskje ikke det som er samfunnsmedisinens viktigste oppgave.» (kommuneoverlege, deltaker 13)

Både i store og små kommuner opplevde kommuneoverleger en overvekt av etterspørsel fra helsetjenesten. Flere beskrev at dette gjorde det vanskeligere å prioritere oppgaver utenfor helsetjenesten. Både forventninger fra ledelsen om rådgivning $\mathrm{i}$ helsetjenesten og manglende tilgang på oppgaver utenfor denne førte til at samfunnsmedisinske oppgaver på overordnet nivå eller i andre sektorer ofte ble nedprioritert, som igjen bidro til uklar rolleforståelse og ambivalens til egen plassering i organisasjonen.

I alle fokusgruppene ble det reflektert rundt hvordan manglende rammer, usynlighet og uklar rolleforståelse også ga mye frihet. Denne autonomien ble høyt verdsatt, særlig med $ø$ kende kompetanse. Det ble likevel problematisert at friheten til å utforme rollen også bidro til en manglende felles forståelse av hva rollen skulle være, siden ingen kommuneoverleger løste dette helt likt.

«Men det er jo et ganske interessant spørsmål, ikke sant. For når du slutter, ville en ny kunne gå inn i din stilling og ha samme rolle som deg? Nei. Det sto ikke noen sko der da jeg kom, og jeg er helt sikker på at når jeg går ut av min stilling, så står de ikke der sånn at nestemann kan hoppe i dem og så gir alt seg selv.» (kommuneoverlege, deltaker 13) 
Så lenge de fikk samfunnsmedisinske oppgaver i hele kommunen, var de fleste kommuneoverlegene enige om at ulik rolleutforming var en styrke. Flere så det som vesentlig for god rolleutøvelse at man kunne tilpasse rollen og oppgavene til de lokale forholdene. Det ble i alle fokusgruppene reflektert rundt balansen mellom styring fra ledelsen og egen autonomi. Noen av kommuneoverlegene med minst erfaring etterlyste mer styring fra ledelsen i starten og så friere tøyler etter hvert. De fleste konkluderte imidlertid med at de ikke ønsket mer faglig styring fra leder, men tettere oppfølging og interesse.

\section{Diskusjon}

Resultatene i studien viste at mange kommuneoverleger opplever usynlighet og rolleuklarhet. Dette ble først og fremst påvirket av organisatorisk ramme, personlige egenskaper og kompetanse samt ledelsens oppfølging og forventninger. I analysen fremkom det også en grunnleggende spenning mellom to ulike identiteter som ble brukt $\mathrm{i}$ stillingen som kommuneoverlege: klinisk identitet og samfunnsmedisinsk identitet. Sammen med de andre faktorene påvirket dette opplevelsen av rollen. Dette er i tråd med litteratur innen hybridledelse (7-11). De fleste leger har en sterk klinisk identitet (7,12). Den kliniske identiteten blir i kommuneoverlegerollen særlig brukt i utøvelsen av klinisk rådgivning inn mot enkeltsaker i helsetjenesten, og den krever klinisk kompetanse, autoritet og synlighet på tjenestenivå i kommunen. Den samfunnsmedisinske identiteten er mer befolkningsrettet og blir særlig brukt i rådgivning på overordnet nivå. Her kreves samfunnsmedisinsk kompetanse, autoritet og synlighet på ledelsesnivå i kommunen. Selv om det er en glidende overgang mellom de to identitetene, kan man forenklet si at de krever ulike rammer og er ment å løse ulike oppgaver.

Både vår studie og andre studier (.7.) viser at enkelte kan stå i hybridroller og veksle mellom identiteter uten at det påvirker opplevelsen og rolleutøvelsen negativt. I våre resultater ga kommuneoverleger fra små kommuner uttrykk for dette. Her var stillingsstørrelse den begrensende faktoren for rolleutøvelse og identitetsutvikling. Vi fant imidlertid at $\emptyset$ kende størrelse på kommuneorganisasjonen kunne gi økt spenn mellom de to identitetene og dermed påvirke balansen og rolleutøvelsen negativt.

Flere kommuneoverleger i større kommuner tok opp organisatorisk ramme og leders forventninger som hemmende for tilgangen på samfunnsmedisinske oppgaver på overordnet nivå og i andre sektorer i kommunen. Dette ble begrensende for deres utvikling av samfunnsmedisinsk identitet og bidro til negativ opplevelse av usynlighet og uklar rolleforståelse. Resultatene antyder at kommunal ledelse og andre kommunale sektorer utenfor helsesektoren ikke anerkjenner samfunnsmedisinsk kompetanse som like relevant og derfor ikke etterspør den like mye som i helsesektoren. Funnene våre støttes av ulike teorier innen organisering og ledelse som sier at den organisatoriske rammen vil ha innvirkning på motivasjon, mestring og rolleforståelse hos den enkelte (144-16). Andre studier, blant annet av Berg og medarbeidere i 2017 (므), underbygger dette.

Studier på hybriditet viser at vektlegging av klinisk identitet vil kunne forsinke utviklingen av administrativ identitet og dermed påvirke ytelsen i rollen negativt (7, 10-12). Ulike teorier om motivasjon viser at vi trekkes mot oppgaver som trigger vår kompetanse og gir mestring $(\underline{17}, 1 \mathbf{1}, 19$.$) . I lys av dette bør kommuner vektlegge utvikling av$ samfunnsmedisinsk identitet $\mathrm{i}$ kommuneoverlegeposisjonen for å påvirke rolleutøvelsen positivt. Da må organisatorisk ramme og forventninger tilrettelegge for samfunnsmedisinske oppgaver på ulike nivåer og sektorer i kommunen. Hvis rammen først og fremst legger til rette for bruk av klinisk identitet, vil dette kunne hindre utviklingen av samfunnsmedisinsk identitet og øke opplevelsen av usynlighet og uklar rolleforståelse. Sammenhengen mellom de grunnleggende identitetene, påvirkningsfaktorene og rolleopplevelsen er fremstilt i figur 1 . 


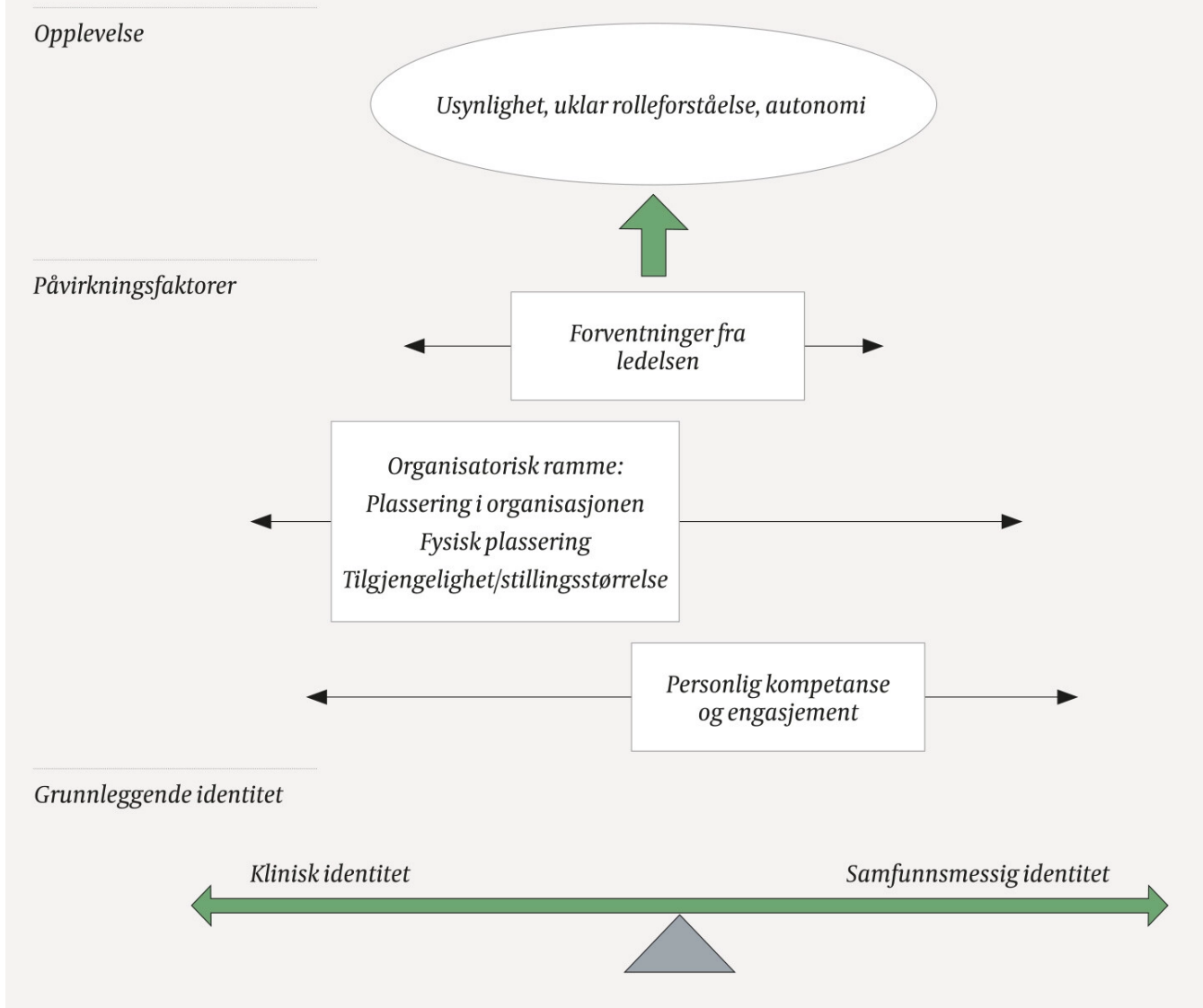

Figur 1 Forenklet fremstilling av sammenhengen mellom identitetskonflikt i bunnen, påvirkningsfaktorer og opplevelser som kommuneoverleger ga uttrykk for.

Studien antyder at kommuneoverleger må ha samsvar mellom de tre påvirkningsfaktorene og samfunnsmedisinsk identitet for at opplevelsen av usynlighet og uklar rolleforståelse skal reduseres og identiteten utvikles. Dette gjelder særlig i store kommuner, hvor en slik tilpasning kan gå på bekostning av klinisk rådgivning i enkeltsaker. I små kommuner synes stillingsstørrelse å være mest avgjørende for kommuneoverlegens opplevelse av rollen.

For å begrense påvirkning fra førsteforfatters forforståelse ble andreforfatter benyttet aktivt gjennom hele prosessen. Fordelen med å ha bakgrunn og erfaring som kommuneoverlege var at det var lettere å skape trygghet og åpenhet i fokusgruppene og lettere å stille oppfølgingsspørsmål og utforske uttalelser nærmere. Fokusgruppene ble gjennomført fysisk. Det medførte at alle informantene var fra $§ ø r-N o r g e$, men med spredning i geografi, kommunal størrelse og erfaring. Det var også en blanding av kjønn, stillingsstørrelse og plassering i kommunen. Alle informantene kunne formidle mye og variert om problemstillingene. Erfaringen fra fokusgruppene var at deltakerne snakket fritt og åpent og med god dialog. Førsteforfatter gjennomførte fokusgruppeintervjuene alene, noe som kan ha ført til at nyanser er gått tapt.

Studien representerer et utvalg kommuneoverlegers opplevelse av egen rolle. Den kan ikke generaliseres til å gjelde alle kommuneoverleger i Norge. Man vurderer likevel at utvalget hadde god informasjonsstyrke, selv med et relativt begrenset antall deltakere. Funnene er derfor sannsynlig relevante og overførbare til flere kommuneoverleger i Norge. Særlig er funnet om rolleuklarhet, som kan ses på i lys av hybriditet, på linje med andre studier (7,$\underline{10-12}$ ). Dette styrker validiteten av funnene. Studien har imidlertid kun tatt utgangspunkt i kommuneoverlegers opplevelse av rollen. Det er ikke utforsket hvilke erfaringer og tanker kommunal ledelse har rundt kommuneoverlegerollen eller hvordan det er tilrettelagt for god rolleutøvelse. Dette kunne brakt ekstra dybde til materialet. 
Studien er gjort like før covid-19-pandemien og gir innsyn i hvordan noen kommuneoverleger i Sør-Norge opplevde egen rolle idet pandemien traff. Siden det har vært stort press, men også økt fokus, på kommuneoverlegerollen under pandemien, hadde det vært svært interessant å gjøre en oppfølgingsstudie etter pandemien for å utforske om, og eventuelt hvordan, dette har ført til endringer i opplevelsen av rollen.

Artikkelen er fagfellevurdert.

\section{REFERENCES}

1. Pasientens primærhelsetjeneste må ledes - om ledelse av det medisinske tilbudet i kommunene. Oslo: Den norske legeforening, 2017. https://www.legeforeningen.no/om-oss/rapporter/pasientensprimarhelsetjeneste-ma-ledes/ Lest 17.11.2021.

2. Kommunal legetjeneste - kan den ledes? Oslo: KS og Agenda Kaupang, 2016.

https://www.ks.no/contentassets/b3154b3436fd4c85beff563a69d17b11/rapport.pdf Lest 17.11.2021.

3. Evaluering av fastlegeordningen. Oslo: EY og Vista analyse, 2019.

https://www.regjeringen.no/contentassets/7cd212bf5fo642c1a5dod48ofog23e6d/evaluering-avfastlegeordningen---sluttrapport-fra-ey-og-vista-analyse.pdf Lest 15.10.2019.

4. LOV-2011-06-24-30. Lov om kommunale helse- og omsorgstjenester m.m. https://lovdata.no/dokument/NL/lov/2011-o6-24-30 Lest 17.11.2021.

5. Nylenna M. Hva er samfunnsmedisin? Michael 2016;13: 79-85.

6. Utvikling av kommunelegefunksjonen. Rapport fra arbeidsgruppe oppnevnt i brev av 24.10.07 fra Sosial- og helsedirektoratet. Oslo: Helsedirektoratet, 2008.

https://kommunelegen.files.wordpress.com/2012/01/k-lege-rapport-avgitt-1-07-o8.pdf Lest 17.11.2021.

7. Spehar I, Frich JC, Kjekshus LE. Professional identity and role transitions in clinical managers. J Health Organ Manag 2015; 29:353-66. [PubMed][CrossRef]

8. Frich JC, Spehar I. Ledelsesutvikling for leger. Tidsskr Nor Legeforen 2018; 138. doi: 10.4045/tidsskr.18.0645. [PubMed][CrossRef]

9. Sartirana M. Beyond hybrid professionals: evidence from the hospital sector. BMC Health Serv Res 2019; 19: 634. [PubMed][CrossRef]

10. Spehar I, Sjøvik H, Karevold KI et al. General practitioners' views on leadership roles and challenges in primary health care: a qualitative study. Scand J Prim Health Care 2017; 35: 105-10. [PubMed][CrossRef]

11. Spehar I, Frich JC, Kjekshus LE. Clinicians in management: a qualitative study of managers' use of influence strategies in hospitals. BMC Health Serv Res 2014; 14: 251. [PubMed][CrossRef]

12. Berg LN, Puusa A, Pulkkinen Ket al. Managers' identities: Solid or affected by changes in institutional logic and organisational amendments? SJPA 2017; 21: 81-101.

13. Malterud K. Fokusgrupper som forskningsmetode for medisin og helsefag. Oslo: Universitetsforlaget, 2012.

14. Malterud K. Kvalitative forskningsmetoder for medisin og helsefag. 4 utg. Oslo: Universitetsforlaget, 2017.

15. Mintzberg H. Organization design: fashion or fit? Harv Bus Rev 1981; nr. Jan-Feb: 103-16.

16. Jacobsen DI, Thorsvik J. Hvordan organisasjoner fungerer. 4. utg. Bergen: Fagbokforlaget, 2018.

17. Ryan RM, Deci EL. Self-determination theory and the facilitation of intrinsic motivation, social development, and well-being. Am Psychol 2000; 55: 68-78. [PubMed][CrossRef]

18. Herzberg F. One more time: how do you motivate employees? 1968. Harv Bus Rev 2003; 81: 87-96. [PubMed]

19. Maslow AH. A theory of human motivation. Psychol Rev 1943; 50:370-96. [CrossRef]

Publisert: 6. januar 2022. Tidsskr Nor Legeforen. DOI: 10.4045/tidsskr.21.0589

Mottatt 13.8.2021, første revisjon innsendt 12.10.2021, godkjent 17.11.2021.

Publisert under åpen tilgang CC BY-ND. Lastet ned fra tidsskriftet.no 26. april 2023. 